\title{
Cutaneous Metastasis of Transitional Cell Carcinoma of Urinary Bladder-An Unusual Case
}

\author{
Vazir Singh Rathee*, Sartaj Wali Khan, Aditya Kumar, Shukla PK, Trivedi S and Dwivedi US \\ Department of Urology, BHU, India
}

*Corresponding author: Vazir Singh Rathee, Department of Urology, IMS, BHU, Varanasi, UP, India

Submission: 泟 September 10, 2017; Published: 侮January 11, 2018

\section{Introduction}

The reported incidence of cutaneous spread from primary urologic malignancies is $1.3 \%$. Urinary bladder malignancies altogether account for $0.84 \%$ of cutaneous metastases [1]. In this case report, we present a patient with transitional cell carcinoma bladder who developed a solitary subcutaneous nodular metastasis in the right gluteal region of two months duration [2].

\section{Case Report}

A 60M presented with total recurrent painless gross haematuria with passage of clots for one year. No history of LUTS. GPE-normal. LE-tender s/c mass of size $4 \times 3 \mathrm{~cm}$, firm, freely mobile, on the (R) gluteal region, local tempt normal (Figure 1) [3].

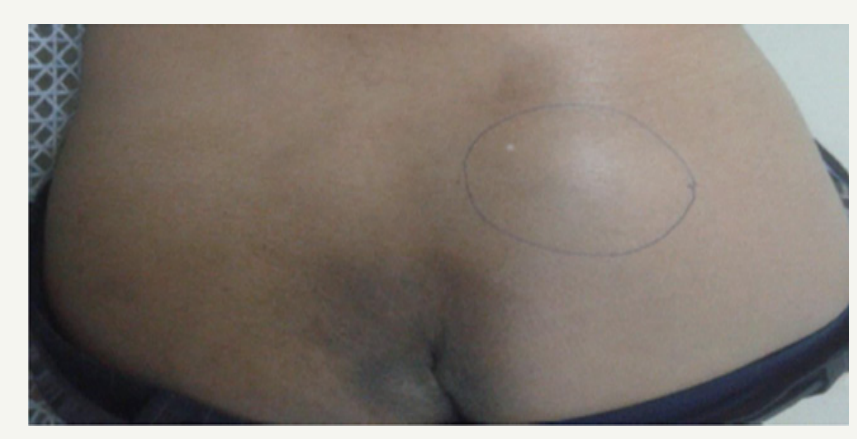

Figure 1: Photograph showing the tender s/c mass of size $4 \times 3 \mathrm{~cm}$, firm, freely mobile, on the right gluteal Region.

\section{Results}

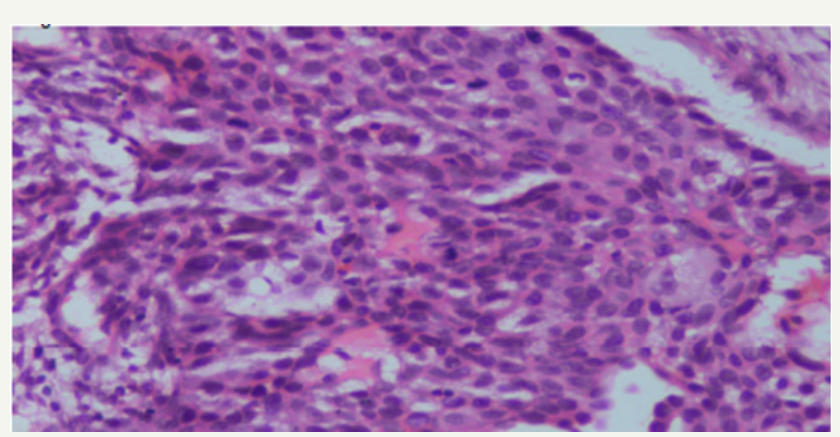

Figure 2: FNAC of the s/c mass-micro photograph showing the infiltration of the skin by the metastatic TCC.
Cystoscopy done a papillary growth of approximately of size $4 \times 3 \mathrm{~cm}$ in the right posterolateral wall and trigone close to bladder neck. No changes suggestive of carcinoma in situ on cystoscopy. TURBT was done. Biopsy-low grade papillary urothelial carcinoma (lamina invasive) [4]. FNAC (fine needle aspiration cytology) of the subcutaneous nodule was strongly suggestive of metastatic deposits of urothelial carcinoma. C.T urography showed metastatic bony lesions in the spine. The patient was referred to radiotherapy department for further treatment (Figure 2).

\section{Conclusion}

This is a rare case of early presentation of cutaneous metastasis of transitional cell carcinoma particularly of low grade type. In many cases, as in our patient, treatment is mainly supportive and prognosis is poor (Figure 3) [5]. Therefore, it is important for the medical community to have access to each case, through case reports, so as to advance our understanding of this particular disease.

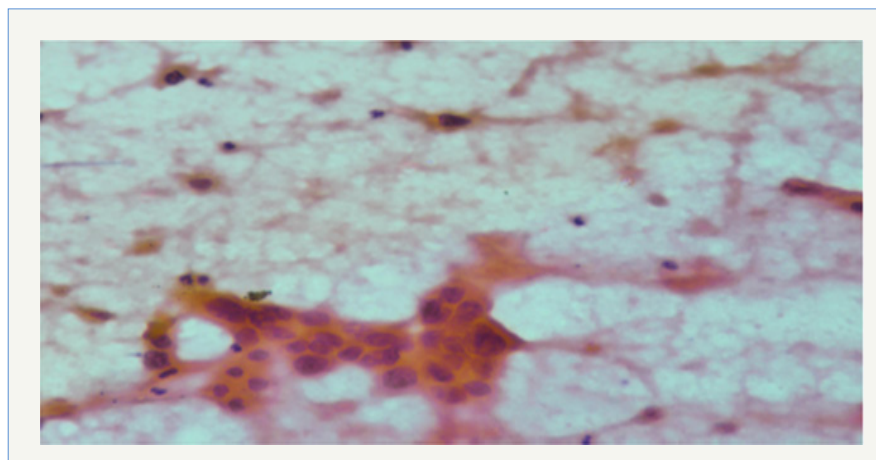

Figure 3: Cold biopsy from bladder growth-microphotograph showing low grade papillary urothelial carcinoma (lamina invasive).

\section{References}

1. Mueller TJ, Wu H, Greenberg RE, Hudes G, Topham N, et al. (2004) Cutaneous metastases from genitourinary malignancies. Urology 63(6): 1021-1026.

2. Fujita K, Sakamoto Y, Fujime M, Kitagawa R (1994) Two cases of inflammatory skin metastasis from transitional cell carcinoma of the urinary bladder. Urol Int 53(2): 114-116. 
3. Messing EM, Catalona W (1998) Urothelial tumors of the urinary tract. Bladder cancer. In: Walsh PC, Retik AB, Vaughan ED, et al. (Eds.), Campbell's Urology. ( $7^{\text {th }}$ edn), W.B. Saunders Co, Philadelphia, USA, pp. 2329-2383.

4. Swick BL, Gordon JR (2010) Superficially invasive transitional cell carcinoma of the bladder associated with distant cutaneous metastases. J Cutan Pathol 37(12): 1245-1250.

5. Block CA, Dahmoush L, Konety BR (2006) Cutaneous metastases from transitional cell carcinoma of the bladder. Urology 67(4): 846. 